UDC 622.6

DOI: http://dx.doi.org/10.20535/2219-380412201561248

S. I. Trubachev ${ }^{1}$, доцент, к.m.н., O. N. Alekseychuk ${ }^{2}$, доцент, к.m.н.

\title{
THE STRENGTH CALCULATION OF ENERGY SYSTEMS PIPELINES WITH BENDS BY FINITE ELEMENT METHOD
}
Ua В роботі розглянута класифікація трубопроводів енергетичних систем їх призначення та розрахунок на міцність з урахуванням вигинів. Розрахун- ки проводились за допомогою програмного комплексу ANSYS, що базується на використанні метода скінчених елементів. Представлені розрахунки еле- ментів трубопроводів з урахуванням реальних умов експлуатації..
Ru В работе рассмотрена классификация трубопроводов, их назначение и расчет на прочность с учетом гибов. Расчеты проводились с помощью про- граммного комплекса ANSYS, который основан на использовании метода конечных элементов. Представленырасчетыэлементовтрубопроводовсуче- томреальныхусловийэксплуатации.

\section{Introduction}

The pipelines are widely used in industry for transporting liquid, gaseous and dry substances.

In connection with a large variety of pipelines the calculations of strength, stiffness and stability are an actual problem when designing is based on actual service conditions. It should be emphasized that a few scientific papers devoted to the calculation of pipelines with bends are based on three-dimensional models or the exact formulation of the problem at the present time [1].

\footnotetext{
${ }^{1}$ Національний техніний університет України “КПГ”, кафедра динаміки і міциності машин та опору матеріалів

${ }^{2}$ Національний техніний університет Украйни “КПГ”, кафедра теоретичної механіки
} 
The calculation of pipelines, as the calculation of rod systems does not always give reliable results without taking into account the distribution of stresses in the places of pipelines fixing, or in places where there are stress concentrators. First of all this is due to the complexity of the mathematical formulation of the problem. To take account all these factors it is necessary to apply numerical simulation that based on variation-grid approaches. The calculation of pipelines with bends that was suggested in this paper is based on a finite element method.

\section{Formulation and solving the problem}

The decision of applied problems with using the numerical methods is based by reducing this problem to a finite-dimensional. For this purpose an infinite dimensional space of admissible functions is substituting by finite dimensional space $V_{b} \subset V$.

To construct a finite-dimensional space $V_{b}$ there are used the way in which basic functions are taking as functions with the final small support, each of which only a relatively small (about step of grid $b$ ) environs different from zero, and outside its identically zero [1]. To constructing them using the grid the discretization of area $\Omega$ that engaged by body is performed on a finite number of subregions $\Omega_{n}$. In combining subregions $\Omega_{n}$, that adjacent to each node grid, basic function is constructed with the final small support, which is a polynomial on each subregions $\Omega_{n}$. All of linearly independent functions of this type are taken as the base.

In the construction of finite spaces a piecewise polynomial functions are used; while the set $\Omega$ is represented as a combining of disjoint polygons $\Omega_{n}$.

The polynomial coefficients in each polygon is selected so that to provide the necessary sleekness, and to provide unambiguous definition of the polynomial from the conditions of belonging of approximate decision to space $V$.

Let $\left\{\varphi_{i}(x)\right\}_{i=1}^{N}$ is the basic system of functions, the $i$-th member of which takes in the $i$-node a value that is equal to one and in other grid nodes it turns to zero. Then the function $v_{b}$ can be represented as:

$$
v_{b}=\sum_{i=1}^{N} v_{i} \varphi(x) .
$$

The linear combination of (1) defines the function $v_{b} \in V_{b}$ on the entire region on its nodal values. The type and properties of variational-grid scheme for this task are depending from the choosing of the grid and the system of basic functions. In the construction of variational-grid schemes the functional of potential energy of the system at finite space of admissible functions $V_{b}$ has the form: 


$$
F(\vec{v})=\frac{1}{2}(C \vec{v}, \vec{v})-(\vec{f}, \vec{v})
$$

where $C$ is the stiffness matrix ; $f$ is the vector of nodal loads.

The variation problem is solved approximately. The approach which based on the necessary condition of the functional minimum is used most commonly (2). Then the problem of solving a system of linear algebraic equations of high order is arises:

$$
C \overrightarrow{\mathrm{v}}=\vec{f}
$$

So we come to the ordinary application of finite element method [2].

Let us consider a bend pipe, which is loaded by the internal pressure $1,2 \cdot 10^{6} \mathrm{~Pa}$ (Fig. 1). The main parameters of a bend are the bend radius $R$, the tube diameter $D$ and the wall thickness $h$. For calculating was used the model of steel pipe with Young's modulus $E=2 \cdot 10^{11} \mathrm{~Pa}$, Poisson ratio $\mu=0,3$ and density $\rho=7800 \mathrm{~kg} / \mathrm{m}^{3}$. The pipe diameter is $220 \mathrm{~mm}$ and wall thickness is $7 \mathrm{~mm}$.

The calculation was made by using the complex ANSYS. As shown in Fig. 2 the distribution of stress fields has significantly inhomogeneous nature. The concentration of the stress occurs on the inside surface of the pipe in place of its greatest curvature.

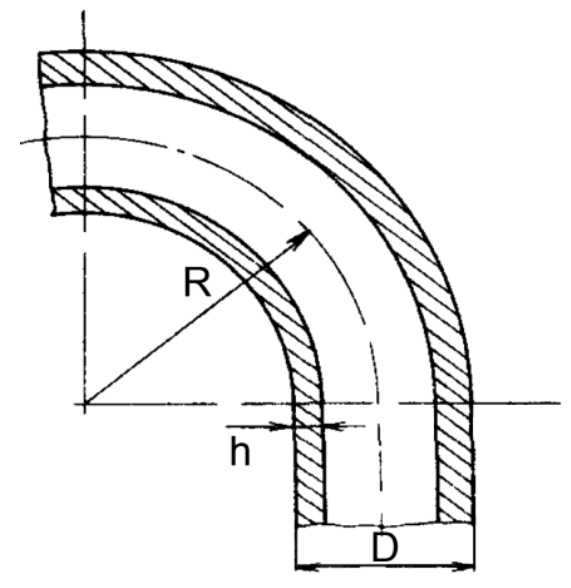

Fig. 1. A bend pipe

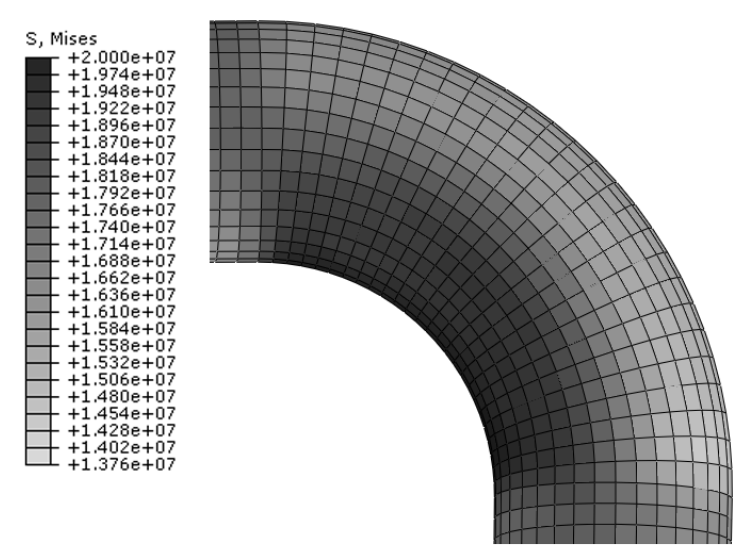

Fig. 2. The distribution of stress fields

The stress concentration coefficient is determined experimentally in most cases [4]:

$$
K=\frac{\sigma_{\max }}{\sigma}
$$

where $\sigma_{\max }$ is the maximum local strain, and $\sigma$ is the nominal tension in the area of the pipeline that is distant from the place of concentration. The use of numerical experiment for determining the stress concentration makes easier the task. Fig. 3 shows the dependence of stress concentration from ratio of bending radius 
to the outer diameter of the pipe. As can be seen from the graph, this dependence has nonlinear character with considerable leap of stress concentration at the values $R$ that are smaller than the diameter of the pipe.

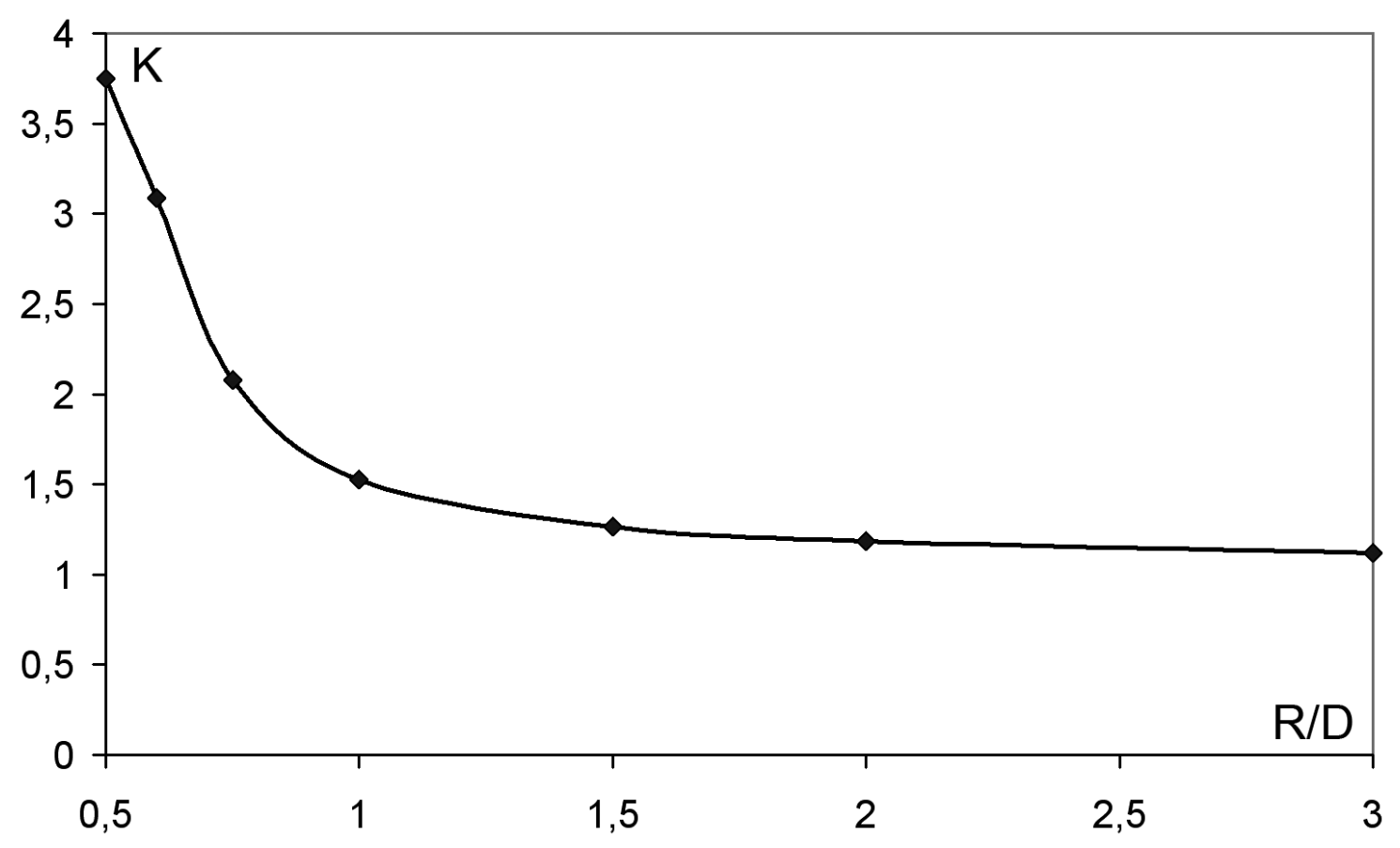

Fig. 3. The dependence of stress concentration from ratio R/D

Constructive elements under external load must be in equilibrium. It means that the system that has lost equilibrium under influence of external factors should be going back to equilibrium with the disappearance of these factors.

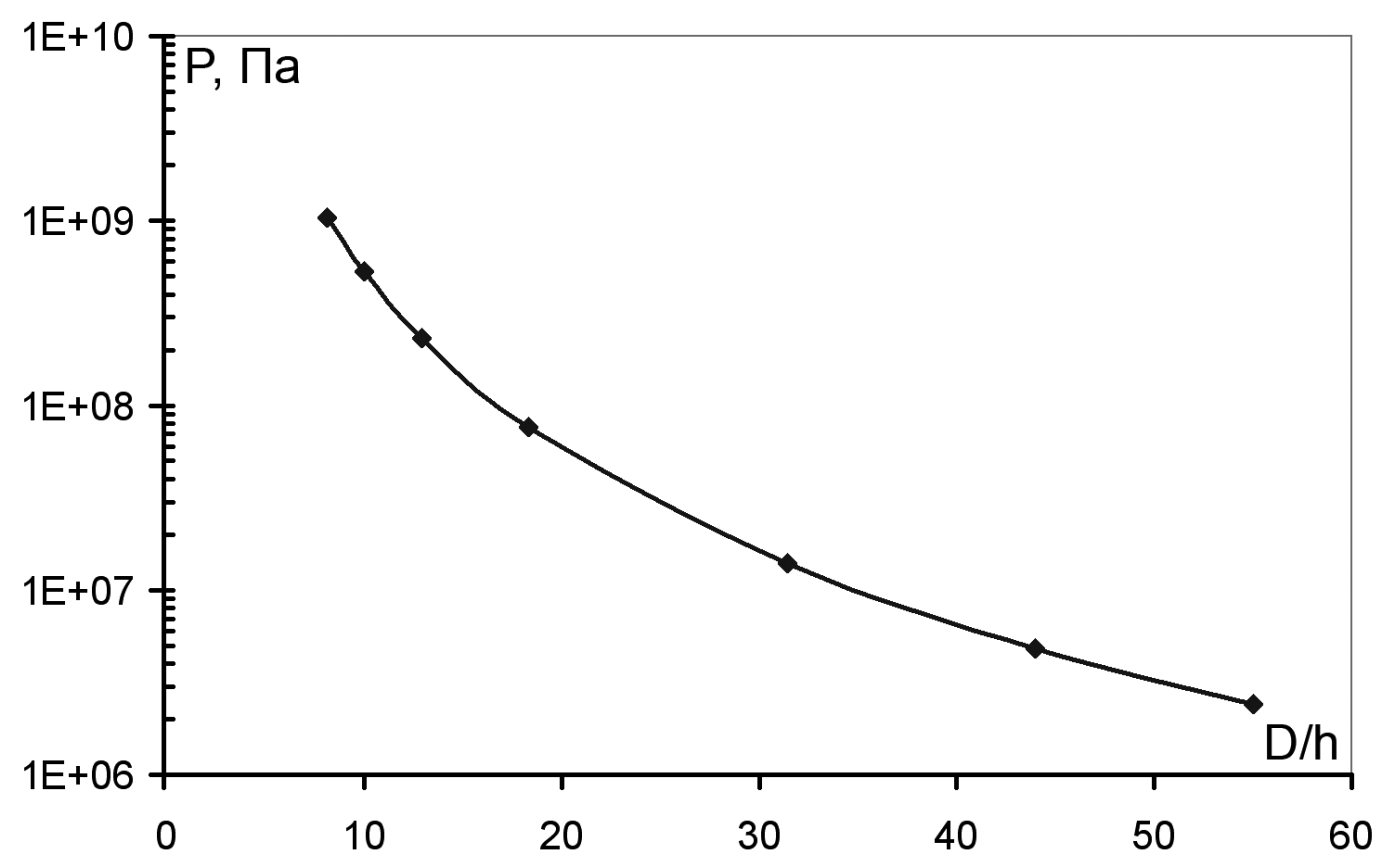

Fig. 4. The dependence of critical external pressure from the thickness of wall 
As the construction loses its stability at first, then it loses strength, therefore, the determination of the absolute value of the critical load is an important problem in the design of pipelines. All elements of hydro technical facilities and pipelines that are loaded by external pressure or inner pressure of which is much small are require the verification calculation of the loss of stability. As a result of numerical experiment for rectilinear steel pipe of relatively infinite length, was obtained the dependence of critical external pressure (Under action of which the construction loses stability) from the thickness of wall (Fig. 4).

\section{Conclusions}

The paper presents an approach to calculation of the strength of pipelines that based on the using of finite element method. This allows us to analyze stress-strain state and sustainability of pipelines with considering the bends and real conditions of operation, which in turn are necessary at the design stage to ensure the strength and reliability of structures.

\section{References}

1. Марчук Г. И. Введение в проекционно-сеточные методы / Г. И. Марчук, В. И. Агошков // - М.: Наука, 1981. - 416 с.

2. Зенкевич О. Метод конечных элементов в технике / О. Зенкевич // - М.: Мир, 1975. - $541 \mathrm{c.}$

3. FKM - Guideline, Analytical Strehgth Assesment of Componenys in Mechanical Engineering, 5th, revised edition, English Version, Forschungskuratorium Maschinenbau (FKM), Frankfurt/Main, 2003 - 268 c. 